\title{
Muhasebe Meslek Mensuplarının Mesleki Faaliyetlerinde Uymaları Gereken Etik İlkelere Uyma Düzeyine Yönelik Meslek Mensupları İle Meslek Yüksek Okulu Muhasebe Bölümü Öğrencilerinin Algıları
}

\author{
Osman AKIN * \\ Kürşat ÖZDAŞLI ${ }^{* *}$
}

\section{$\ddot{O Z Z E T}$}

Küreselleşme ve bilgi toplumu olma gibi gelişmelere uyum sağlayabilmek ve güvenilir, sağlıklı bir ekonomik hayat oluşturabilmek için bütün dikkatler meslek ahlakı ve meslek etiği gibi kavramlar üzerinde odaklanılmasını sağlamıştır. Etik; değerleri, ahlaki bakımdan iyi ya da kötü, doğru ya da yanlış olanın niteliğini ve temellerini araştıran felsefedir. Meslek etiği ise bir meslekle ilgili daha önce belirlenmiş olan genel kabul görmüş kurallar bütünüdür. Her meslekte olduğu gibi muhasebecilik mesleğinde de meslek mensuplarının uymaları gereken etik kurallar söz konusudur. Meslek mensupları mesleki faaliyetlerini gerçekleştirirken dürüst olma, tutarlı doğru karar alma, tarafsız olma ve mesleki davranışlarına özen gösterme gibi birtakım kurallara uymak yükümlülügündedir.

Çalışmamızda, muhasebe meslek mensupları ile meslek yüksek okulu ögrencilerinin etik kavramının algılanmasına yönelik mesleki etik kuraları yönetmeliği kapsamında yer alan dürüstlük, tarafsızlık, gizlilik, mesleki yeterlilik ve özen ve mesleki davranış gibi etik boyutlar baz alınarak karşılaştırmalı bir analiz yapılmıştır. Araştırma sonucunda, muhasebe eğitimi alan ögrencilerin muhasebe mesleğini icra eden meslek erbabina kiyasla dürüstlük ve şeffaflık ilkelerinin meslek mensupları tarafindan daha fazla ihlal edildiğini düşündükleri tespit edilmiştir.

Anahtar Kelimeler: Etik, Meslek Etiği, Muhasebe Meslek Etiği.

JEL Sinıflandırması: M41, M49.

Professional Accountants Professional Activities should comply with the Ethical Principles Regarding Compliance Professionals With Level Vocational High School Students' Perceptions of Accounting Department

\section{ABSTRACT}

Businesses have focused on the concepts such as professional ethics in order to create a healthy economic life and to adapt to the developments such as globalization and being an information society. Ethics is the philosophy that investigates the nature and basis of values whether they are morally good or bad, right or wrong. Professional ethics is generally accepted as set of rules previously determined and related to the profession. As in every profession, professionals in accountancy profession should follow the ethical rules that profession is concerned. While performing their professional activities, professionals are obliged to comply with certain rules such as being honest, giving consistent and accurate decision, being impartial and complying with the professional behaviour.

In our study, a comparative analysis has been carried out by mainly discussing honesty, impartiality, confidentiality, professional competence and due care and professional behaviour within the scope of accounting profession perception of vocational high school students and professionals. Based on the results of the study, we have determined that, if they are compared to professionals of accountancy, accounting students think principles of honesty and transparency are violated more by the professionals.

Keywords: Ethics, Business Ethics, Accounting Profession Ethic.

Jel Classification: M41, M49.

\footnotetext{
* Yrd.Doç.Dr. Osman Akın, Mehmet Akif Ersoy Üniversitesi Zeliha Tolunay Uygulamalı Teknoloji ve İşletmecilik Yüksekokulu,osmanakin@mehmetakif.edu.tr.

** Doç.Dr. Kürşat Özdaşlı, Mehmet Akif Ersoy Üniversitesi İktisadi ve İdari Bilimler Fakültesi, kozdasli@mehmetakif.edu.tr.
} 


\section{GíRiş}

Büyüme sürecini yaşamaya başlayan işletmelerin doğal olarak daha karmaşık bir yap1 haline gelmeleri söz konusu olmaktadır. Bu işletmeler açısından ekonomik ve sosyal sürdürülebilirlik en önemli durum haline gelmektedir. Sürdürülebilirliği sağlamakla yükümlü olan işletme yönetiminin temel görevi; işletmelerin yaşamlarını sürdürebilmeleri ve gelişmeleri için uygun ortamın yaratılması için gerekli olan bilgileri sağlamaktır. İşletmeler için gerekli olan bu bilgilerin sağlanmasında ise muhasebe bilgi sisteminin önemli hale geldiği görülmektedir. Çünkü muhasebe; mali nitelikteki işlemleri ve olayları para ile ifade edilmiş şekilde kaydetme, sınıflandırma, özetleme, analiz etme, yorumlama ve raporlama süreci olarak tanımlanmaktadır (Acar ve Tetik, 2006: 8).

Muhasebeci ise; mali nitelikteki işlemleri ve olayları para ile ifade edilmiş şekliyle kaydeden, sınıflandıran, özetleyen, analiz eden, yorumlayan ve raporlayan kişi şeklinde tanımlanabilir.

Ülkemizde muhasebecilik mesleği 3568 sayılı yasa ile meslek statüsüne kavuşturulmuştur. 3568 Sayılı serbest Muhasebecilik, Serbest Muhasebeci Mali Müşavirlik ve Yeminli Mali Müşavirlik Kanunu, muhasebecilik mesleğini icra edenleri üç statüde değerlendirmiştir. Bunlar; ( 3568 Sayılı serbest Muhasebecilik, Serbest Muhasebeci Mali Müşavirlik ve Yeminli Mali Müşavirlik Kanunu Madde 1)

- $\quad$ Serbest Muhasebeci,

- $\quad$ Serbest Muhasebeci Mali Müşavir,

- Yeminli Mali Müşavir.

Adı geçen kanunda muhasebe mesleğinin konusu özetle; defter tutmak, tablo ve beyannameler düzenlemek, muhasebe sistemleri kurmak, müşavirlik, bilirkişilik ve benzeri işleri yapmak şeklinde ifade edilmektedir (Kutlu, 2008: 145).

İşletme yönetimine ihtiyaç duyduğu bilgileri sağlama misyonunu da yüklenen muhasebe fonksiyonun sadece defter tutmak gibi dar bir alana sıkıştırılamayacağ muhakkaktır. Bu nedenle günümüzde muhasebe; toplumun her kademesinden gelen taleplere yanıt vermek, müşterilerin gereksinmelerini karşılamak, yöneticilere karar almada yardımcı olmak, işletmelerin devlete karşı görevlerini yerine getirirken doğru ve güvenilir bilgiler sağlamak, yatırımcılara gerekli bilgileri aktarmak gibi alanlarda etkili bir fonksiyon haline gelmiştir. Bu durum, muhasebecilik mesleğinin önemi daha da artırmaktadır (Nalbantoğlu, http://archive.ismmmo.org.tr).

Muhasebe mesleğinin 3568 sayılı kanun ile yasal statüye kavuşmasından sonra, Dünya'daki uygulamalara paralel olarak mesleki unvan verme ve mesleki yeterliliği değerlendirme yetkisi ülkemizde muhasebe mesleğinin üst örgütü olan Türkiye Serbest Muhasebeci, Mali Müşavir ve Yeminli Mali Müşavirler Odaları Birliği’ne (TÜRMOB) verilmiştir. 1992 yılında TÜRMOB tarafindan Serbest Muhasebecilik, Serbest Muhasebeci 
Mali Müşavirlik Staj Yönetmeliğini Resmi Gazete'de yayınlanarak yürürlüğe girmiş ve 1997 yılında yapılan düzenleme ile bugünkü halini almıştır. $\mathrm{Bu}$ yönetmelikle, aday meslek mensuplarının mesleğe ilk girişleri, yetiştirilmeleri ve mesleğe hazırlanması için staj programlarının geliştirilmesi, stajlarda uygulanacak değerlendirme yöntemleri ve diğer uygulamalar yazılı esaslara bağlanmıştır. Ayrıca 1993 yılında Türkiye Serbest Muhasebeci Mali Müşavirler ve Yeminli Mali Müşavirler Temel Eğitim ve Staj Merkezi (TESMER) kuruluş, çalışma yöntem ve esasları hakkındaki yönerge yayınlanmış ve TÜRMOB'un denetimi ve koordinasyonu ile stajyer meslek mensuplarının staj, eğitim ve değerlendirme sınavları bu merkezler aracılığı ile yürütülmeye başlanmıştır. TESMER, aynı zamanda meslek mensuplarının meslek içi eğitimlerini de yapmaktadır (Yardımcıoğlu vd., 2006: 173).

Her meslek te olduğu gibi muhasebecilik mesleğinde de etiğin mesleki uygulamalarda önemli bir belirleyici olması söz konusudur. Her toplum kendi yaşamını düzenleyebilmek için hayatın her alanını kapsayan çeşitli kurallar ortaya koymuştur. Gelenekler, görenekler, adetler, dini kurallar, iktisadi kurallar, hukuki kurallar ve mesleki özelliklere göre belirlenen mesleki kurallar hayatımıza belirli bir düzen getirir. Toplumlar geliştikçe oluşturulmuş olan kurallar da değişerek zamana uygun hale getirilir (İşgüden ve Çabuk, 2006:60-61).

Etik kavramı eski çağlardan beri insan ilişkilerinde önemli bir yere sahip olmuştur. Diğer taraftan insanların meslek hayatlarındaki etkisi de göz ardı edilmemelidir. Bilgi teknolojilerinin hızlı bir gelişme gösterdiği 2000'li yıllarda ise etik kavramı boyut değiştirerek birçok disiplin açısından en fazla araştırmaya konu olan çalışma alanlarından birisi olmuştur. Etik, üzerine çok çalışılmış bir olgu olmakla birlikte en çok suiistimal edilen hususlardan bir tanesidir (Ünsal, 2009: 412).

Etikle ilgili çalışmalar 2500 yıl öncesine dayanmasına karşın sosyal ve mesleki yaşantımızdaki yeri ise çok daha yenidir. Son yıllarda sıç̧a etik kavramında bahsedilmesine rağmen, çerçeve bir tanımı yapılamamaktadır. Oldukça karmaşık olan etik kavramı ile yapılan çeşitli tanımlamaların hep bir tarafı eksik kalmaktadır (Aymankuy ve Sarığlan, 2005: 25). Etik, yaşamın her alanında davranışları yönlendiren standartların ve prensiplerin bir bütünü olarak doğruyu ve yanlışı ayırt etmek biçiminde algılanmış ve tarihsel süreç içinde farklı toplumlar ve kültürler hep kendi kurallarını oluşturmuşlardır. Bu kuralların temelleri bazen dine ve geleneklere, bazen de meslek gruplarının özelliklerine bağlı olarak şekillenmiştir. Bu bağlamda özellikle son yıllarda genel olarak etik ve meslek etiği, dünyada ve ülkemizde neredeyse her alanda gündeme gelmektedir (Sakarya ve Kara, 2010:57).

Etik kelimesi yunanca "ethos" kelimesinin Türkçede kullanılan karşılığıdır. Ethos kelimesi karakter, adet (usul) veya gelenek anlamına gelmektedir. Türkçede “ahlak” olarak kullanılan kavram Latince'de "morality" kelimesi ile yakın anlamda davranış, adet ve alışkanlık anlamına gelmektedir (Yatkın, 2008:213). İnsanoğlu eski çağlardan beri neyin doğru neyin yanlış olduğu konusunda sürekli doğruyu arama arayışında olmuştur. Neyin doğru ya da yanlış olduğu bazen tesadüfen, bazen kötü tecrübelerden, bazen ise sistemli yaklaşımlar ile bulunmuştur. Doğru ve yanlışın bulunmasında insanın kontrol edebildiği 
sistemli yaklaşımıdır diğer bir ifade ile etiktir. Çünkü etik bir sistemler kümesidir (Ünsal, 2008:1).

Etik; geçmiş, günümüz ve gelecekte insanların tutum ve davranışlarının iyi ya da kötü, doğru veya yanlış yönden değerlendirilmesini içeren ve dünyanın her yerinde geçerli olan ilke ve kuralların bütünü olarak tanımlanabilir. Aynı zamanda felsefenin bir kolu olarak etik; tutumların, davranışların, düşüncelerin, inançların, eylemlerin vb. ahlaki vasıfların, insani değerler açısından iyi, doğru ve kabul edilebilir olup olmadıklarına ilişkin çalışmaları içermektedir (Yatkın, 2008:213).

Etiğin üç ana dalı; "tanımlayıcı etik", "etik felsefesi” (etik teorisi) ve "uygulamalı etik"tir. Tanımlayıcı etik, insanların ve kültürlerin mevcut inançlarını, adet ve geleneklerini, ilkelerini ve uygulamalarını araştırır ve tespite uğraşır. Etik felsefesi, iyi-kötü-hoşgörü gibi etik kavramlarını anlamaya ve etik ilkelerini ve teorilerini doğrulamaya çalışır. Uygulamalı etik ise, evlilik dışı ilişkiler, idam cezası, ötenazi ve sivil itaatsizlik gibi ahlak sorunlarına odaklanır (Pojman ve Fieser, 2009: 2-3).Muhasebecilik Mesleği açısından düşünüldüğünde etik, diğer mesleklerde olduğu gibi, uygulamalı etiğini bir alanı olarak görülmelidir. $\mathrm{Bu}$ çalışmamızda temel amacımız, muhasebe mesleğinde etiğin boyutlarını inceleyerek, bu mesleğe adım atmış bireylerle mesleğin başlangıcında, eğitim sürecinde olan bireyler arasında tutum farklılıklarının ortaya çıkarılmasıdır. Bu amaç doğrultusunda öncelikle muhasebecilik mesleğinde etik boyutu irdelenecektir.

\section{MUHASEBECILİK MESLEĞİNDE ETIK}

Bir uğraşın meslek olarak kabul edilmesi ile ilgili temel unsurları dikkate aldığımızda etiğin her meslek gibi muhasebecilik mesleği açısından da temel şartlardan biri olduğunu görürüz. Bir uğraşın meslek olarak kabul edilebilmesi için; a. o meslekle ilgili bir grup kimliğinin oluşması, b. mesleğe giriş için yasal olarak gerekli olan eğitim ve öğretim süreçleri, c. özel, herkesin sahip olmadığı mesleki bilgi, d. pozitif sosyal ihtiyaçları karşılamak için gerekli bilgi, e. bireysel muhakeme ve karar vermede özerklik ve e. önceden belirlenmiş değerlere bağlılık (Strahlendorf, www.bcsp.org: 1) gibi şartlar gereklidir. Bu şartlar dikkatle okunduğunda bir mesleğin eğitimle ilgili şartlarının yanı sıra etik kodlarla ilgili olarak da şartlarının olduğu görülecektir.

Günümüz küreselleşme ortamında her olguda değişim meydana geldiği gibi bireylerin değer yargılarında da bir değişim söz konusudur. Bireylerin değer yargılarındaki bu değişim icra etmiş oldukları mesleklerine de yansımakta ve yapılan işin güvenilirliğini daha da önemli hale getirmektedir. Meslek mensuplarının topluma, müşterilerine ve meslektaşlarına karşı güvenilirlik kazanabilmeleri için bir takım ahlaki ve kişisel değerlere uymaları gerekmektedir. (Kiracı ve Elitaş, 2009:66). Meslek mensuplarının bu tür yetilere sahip olması gerekliliği ise etik kavramını, bu kavrama farkındalığın kazandırılmasında da etik eğitimi ortaya çıkarmaktadır. 
Etik eğitimi, gerek davranışlarında gerekse mesleki anlamda alacakları kararlarda etiksel bir boyut olduğunu kavratmaya, kişilerin mesleki olarak ortaya çıkacak olan etiksel sorunları anlamaya ve çözümü noktasında beceri kazandırmaya yönelik yapılan faaliyetlerin tümü olarak tanımlanabilir (Taştan, 2009: 286). Mesleğe girişte temel şartlardan biri daha önce bahsettiğimiz gibi etik kodlar ise, nitelikli ve ahlaklı insan yetiştirme çabaları her meslekte olduğu gibi muhasebe mesleğinin de temel sorunudur (Uçma, 2007: 36). Muhasebe mesleğine toplum tarafından güven duyulması, muhasebe meslek mensuplarının meslekleri ile ilgili her türlü iş ve eylemlerinde mesleğin etik ilkelerine uygun davranmaları ile mümkün olacaktır (Yıldız, 2010: 156).

Etik eğitiminin amacı; muhasebe uygulamalarında karşılaşılan etik sorunlara karş1 meslek adaylarına farkındalık kazandırmak, sorunların çözümünde ahlaki yetilere sahip olmalarını sağlamaktır.

Etik eğitiminde bu amacın gerçekleştirilebilmesi için meslek adayı öğrenciler üzerinde en fazla durulması gereken unsurdur. Ancak en az öğrenciler kadar eğitmen ve eğitim programı da önemlidir. Bu nedenle muhasebe öğreticilerinin etik konuları hakkında geniş bilgi sahibi olmaları ve bu konuda tüm sorumluluğu üstlenerek öğrencilerin gelişimlerini sağlamaları gerekmektedir. (Taştan, 2009: 288)

Muhasebe öğreticilerinin etik konusunda gereken bilgiyi muhasebe öğrencilerine aktarabilmeleri için öncelikle her meslekte olduğu gibi muhasebe mesleğinde de mevcut olan etik kurallara hâkim olması gerekmektedir. Bu kuralların bir bölümü hukuki çerçevede yasalaştırılmış bir bölümü ise meslek örgütleri tarafından yazılı kurallara dönüştürülmüştür. Gerek uluslar arası düzeyde gerekse ülkemiz sınırları dâhilinde yapılan kapsamlı çalışmalar neticesinde muhasebe mesleğinde etik değerler oluşturulmuştur. Ülkemiz de etik ile ilgili gerçekleştirilen çalışmaları dolaylı ve dolaysız yapılan düzenlemeler olarak sınıflandırmak mümkündür. Muhasebe meslek etiğine ilişkin yapılan dolaylı düzenlemeler: (Sakarya ve Kara, 2010:58)

- $\quad$ Maliye Bakanlığı Tarafindan Yapılan Düzenlemeler

- $\quad 3568$ Sayılı Serbest Muhasebecilik, Serbest Muhasebeci Mali Müşavirlik ve Yeminli Mali Müşavirlik Kanunu

- $\quad$ Serbest Muhasebecilik, Serbest Muhasebeci Mali Müşavirlik ve Yeminli Mali Müşavirlerin Çalışma Usul ve Esasları Hakkındaki Yönetmelik

- $\quad$ Serbest Piyasa Kurulu Tarafindan Yapılan Düzenlemeler

Meslek etiğine ilişkin dolaylı olarak yapılan çalışmaların yanı sıra doğrudan yapılan düzenlemeler de söz konusudur. Bunlar;

- $\quad$ Serbest Muhasebeci, Serbest Muhasebeci Mali Müşavirlik ve Yeminli Mali Müşavir Meslek Ahlakı Kuralları İle İlgili Mecburi Meslek Kararı 
- $\quad$ Serbest Muhasebeciler, Serbest Muhasebeci Mali Müşavirler Ve Yeminli Mali Müşavirlerin Mesleki Faaliyetlerinde Uyacakları Etik İlkeler Hakkında Yönetmelik

Şüphesiz ki etik ile ilgili uluslar arası yapılan çalışmalar ülkemiz çalışmalarına ışık tutmaktadır. Uluslar arası düzeyde meslek etiği ile ilgili çalışmaları yapan kuruluşların başında IFAC (Uluslar arası Muhasebeciler Federasyonu-International Federation of Accountants Ethics Committe) ve AICPA (Amerika Kamu Muhasebecileri Enstitüsü-The American Institute of Certified Public Accountants) gelmektedir (İşgören ve Çabuk 2006: 68).

Meslek etiği ile ilgili meslek adaylarını bir başka deyişle öğrencilere gerekli eğitimi verecek olan eğitmenin, muhasebe ile ilgili kavramlar ve uygulamaları bilmesinin yanı sira yukarıda belirtmiş olduğumuz, ülkemizde ve uluslararası düzeyde etik ile ilgili yapılan çalışmaları bilmesi gerekmektedir.

Türkiye açısından Muhasebe meslek etiğinin ilkeleri, 3568 sayılı yasa kapsamında Resmi Gazete'de 19.10.2007 tarihinde "Serbest Muhasebeciler, Serbest Muhasebeci Mali Müşavirler ve Yeminli Mali Müşavirlerin Mesleki Faaliyetlerinde Uyacakları Etik İlkeler Hakkında Yönetmelik" kapsamında belirlenmiştir. Bu yönetmeliğe göre, temel etik ilkeleri dürüstlük, tarafsızlık, mesleki yeterlilik ve özen, gizlilik ve mesleki davranış olarak sınıflandırılan etik ilkelerinden oluşturulan beş boyut kullanılmıştır. Söz konusu yönetmeliğin ilk maddesinde meslek mensuplarının uymaları gereken etik ilkeler beş temel başlık altında toplanmıştır (Sakarya ve Kara, 2010:61). Bunlar:

- Dürüstlük: Meslek mensuplarının tüm mesleki iş ilişkilerinde doğru sözlü ve dürüst davranmalıdır.

- Tarafsızlık: Yanlı ve ön yargılı davranarak; üçüncü kişilerin haksız ve uygunsuz biçimde yaptıkları baskıların meslek mensuplarının mesleki kararlarını etkilememesi ve engellememesidir.

- $\quad$ Gizlilik: Meslek mensubunun mesleki ilişkileri sonucunda elde ettiği bilgileri açıklamasını gerektirecek bir hak veya görevi olmadıkça üçüncü kişi veya gruplara açıklamaması ve bu bilgilerin meslek mensubunun veya üçüncü kişilerin çıkarları için kullanılmamasidır.

- $\quad$ Mesleki Yeterlilik ve Özen: Meslek mensubunun meslekî faaliyetlerini yerine getirirken teknik ve meslekî standartlara uygun olarak, özen ve gayret içinde davranmasıdır.

- Mesleki Davranış: Meslek mensubunun mevcut yasa ve yönetmeliklere uymasını ve mesleğin itibarını zedeleyecek her türlü davranıştan kaçınmasını ifade etmektedir (http://www.resmigazete.gov.tr.).

Muhasebe meslek mensuplarının ve muhasebe alanında eğitim alan öğrencilerin muhasebe mesleğinin etik ilkelerine uyulup uyulmadığına ilişkin görüşlerinin almak üzere yapmış olduğumuz araştırmada bu ilkelere yönelik olarak bir ölçek kullanılmıştır. 


\section{ARAŞTIRMA}

\subsection{Araştırmanın Amacı}

Araştırmanın temel amacı, muhasebe meslek mensupları, ile meslek yüksek okulu öğrencilerinin muhasebe meslek mensupları mesleği icra ederken etik ilkelere ne kadar riayet ediyorlar sorusuna verdikleri cevabı bulmaktır. Bu amaç doğrultusunda öğrencilerle meslek mensuplarının ilkelerin hayata geçirilmesi noktasında görüş farklılıklarının olup olmadığının tespit edilmesi de söz konusu olacaktır. Yapılan yazın taraması ve incelemeler sonucunda etik ile ilgili çalışmaların son yıllarda Türkiye'de ve dünyada artmaya başladığı görülmektedir. Muhasebe mesleğinde etik konusunda yıllara dayanan uzun bir yazın geçmişi olmakla birlikte muhasebe alanında meslek mensupları ve MYO öğrencilerin etik algısına yönelik gerçekleştirilen çalışma sayısı oldukça kısıtlıdır. Bu nedenle meslek mensupları ile MYO öğrencilerinin etik kavramını algılamalarının incelenmesi bundan sonra bu konularda gerçekleştirilecek araştırmalara veri sağlayacak ve yazına katkıda bulunacaktır.

\subsection{Anket Formu ve Ölçekler}

Araştırmada veri toplama aracı olarak anket tekniği kullanılmıştır. Anket formunda 3568 sayıl1 yasa kapsamında resmi gazetede 19.10.2007 tarihinde "Serbest Muhasebeciler, Serbest Muhasebeci Mali Müşavirler ve Yeminli Mali Müşavirlerin Mesleki Faaliyetlerinde Uyacakları Etik İlkeler Hakkında Yönetmelik" yayınlanmıştır. Bu yönetmeliğe göre, temel etik ilkeleri dürüstlük, tarafsızlık, mesleki yeterlilik ve özen, gizlilik ve mesleki davranış olarak sınıflandırılan etik ilkelerinden oluşturulan 5 boyut kullanılmıştır. Söz konusu ölçeğin oluşturulmasında Sakarya Şakir ve Kara Suat (2010) “Türkiye'de Muhasebe Meslek Etiğine Yönelik Düzenlemeler ve Meslek Mensupları Tarafindan Algllanması Üzerine Bir Alan Araştırması" isimli makaleden de yararlanılmıştır.

Muhasebe mesleğinde etik ölçeği, 5 boyutu ile alınmış olunup, 1-5. sorularda dürüstlük boyutunu, 6-10. sorularda tarafsızlık boyutunu, 11-16. sorularda mesleki yeterlilik ve özen boyutunu, 17-21. sorularda gizlilik boyutunu, 22-26. sorularda mesleki davranış boyutunu ortaya koymak amaçlanmıştır..

Ölçeklerde yer alan ifadelerin yanıtları için beş aralıklı Likert tipi metrik ifade kullanılmıştır. Örneğin, "ülkemizde meslek mensuplarının etik ilkeleri uygulamada yeterli özeni gösterdiğini düşünüyorum" ifadesinin yanıtı için "1-Hiçbir zaman", "2-Çok Nadiren", "3-Ara Sıra", "4-Sıklıkla","5-Her Zaman" gibi beş seçenek bulunmaktadır. Buna ilaveten, öğrenciler, meslek mensubu ve muhasebe çalışanlarının demografik yapısını incelemek amacıyla 6 soru sorulmuştur. Geri dönen anket formlarındaki cevaplar kodlanarak "SPSS for Windows 15.0 sürümü” ile analiz edilmiştir. 


\subsection{Veri Hazırlama}

Araştırma neticesinde elde edilen veriler SPSS 15.0 paket programına yüklendikten sonra ilk iş olarak veri dosyasını hazırlamak için; kayıp veri, uç değer, normallik, homojenlik test edilmiştir.

Kayıp veri: Her bir ankette cevabı boş bırakılan maddelerin toplam maddelere oranı \%15 ve yukarısı olup olmadığına bakılmış. Böyle bir anket olmadığı için kayıp veriye atama işlemi yapılmamıştır.

Uç Değer: "Z" ve "T" puanları +3 ve -3 üzerinde olan 25 adet anket analiz diş1 bırakılmıştır. Toplamda 175 anketlik veri analize alınmıştır.

Homojenlik : Yapılan "homogenity test" sonucunda sig. değeri 0.05 'ten büyük çıktığ 1 için verilerin homojen olduğuna karar verilmiştir.

\subsection{Bulguların Değerlendirilmesi}

Araştırma bulgularının değerlendirilmesinde ilk olarak demografik bulgular ele alınmıştır.

Tablo 1: Demografik Bulgular

\begin{tabular}{|l|l|l|}
\hline Cinsiyet & Kişi Sayısı (N) & Yüzde (\%) \\
\hline Bay & 83 & 47,4 \\
\hline Bayan & 92 & 52,6 \\
\hline Yaş & Kişi Sayısı (N) & Yüzde (\%) \\
\hline 18-25 Arası & 143 & 81,7 \\
\hline 25-35 Arası & 22 & 12,6 \\
\hline 37 ve üzeri & 10 & 5,7 \\
\hline Çalışma Yılı & Kişi Sayısı (N) & Yüzde (\%) \\
\hline 1-5 yıl arası & 70 & 40,0 \\
\hline 5-10 yıl arası & 17 & 9,7 \\
\hline 11 yıl ve üzeri & 17 & 9,7 \\
\hline Hiçbiri & 71 & 40,6 \\
\hline Eğitim Düzeyi & Kişi Sayısı (N) & Yüzde (\%) \\
\hline Ortaokul & 1 & 0,6 \\
\hline Lise & 11 & 6,3 \\
\hline Ön lisans & 133 & 76 \\
\hline
\end{tabular}




\begin{tabular}{|l|l|l|}
\hline Lisans & 30 & 17,1 \\
\hline Aylık Gelir & Kişi Sayısı (N) & Yüzde (\%) \\
\hline $1500-2500$ arası & 151 & 86,3 \\
\hline $2501-3500$ arası & 16 & 9,1 \\
\hline $3501-4500$ arası & 5 & 2,9 \\
\hline 4500 ve üzeri & 3 & 1,7 \\
\hline Mesleki Unvan & Kişi Sayısı (N) & Yüzde (\%) \\
\hline $\begin{array}{l}\text { Meslek } \\
\text { Mensubu }\end{array}$ & 59 & 33,7 \\
\hline $\begin{array}{l}\text { Muhasebe } \\
\text { Programı } \\
\text { Öğrencisi }\end{array}$ & 116 & 66,3 \\
\hline
\end{tabular}

Araştırmaya katılanların \%47,4'ü erkek, \%52,6's1 erkektir. Ankete katılanların \%81,7'si 18-25 yaş aralığında, \%12,6's1 25-35 yaş aralığında, \%5,7 si ise 37 yaş ve üzerinde bulunmaktadır. Çalışma süreleri incelendiğinde \%40'1 1-5 y1l arası, \%9,7'si, 5-10 yıl arası ve yine aynı orandaki kısmı 11 yıl ve üzerinde çalıştıkları görülmekle birlikte \%40,6'sının herhangi bir iş tecrübesinin bulunmadığı gözlenmektedir. Araştırmaya katılan eğitim düzeyleri ile ilgili soruda \%0,6 ortaokul, \%6,3 lise, \%34 ön lisans, \%17,1 lisans mezunlar1 bulunduğu saptanmıştır. Aylık gelir incelendiğinde \%86,3'ünün 1500-2500 arası, \%9,1'inin 2501-3500 aras1, \%2,9'unun 3501-4500 aras1 ve \%1,7'sinin 4500 ve üzeri gelire sahip olduğu görülmektedir. Araştırmaya katılanların \%33,9' unu meslek mensubu oluştururken \%66’3'ünü ise muhasebe programı öğrencileri oluşturmaktadır.

Tablo 2: Meslek Mensupları ve Öğrencilerin Meslek Etiği İle İlgili Sorulara Vermiş Oldukları Yanıtların Ortalamaları

\begin{tabular}{|l|c|c|c|}
\hline SORULAR & $\mathrm{N}$ & Ortalama & $\begin{array}{c}\text { Standart } \\
\text { Sapma }\end{array}$ \\
\hline $\begin{array}{l}\text { Meslek mensuplarının mükelleflere ait bilgileri } \\
\text { üçüncü kişiler ile paylaşmadığını düşünüyorum. T* }\end{array}$ & 175 & 2,23 & 1,074 \\
\hline $\begin{array}{l}\text { Meslek mensupları yasa ile belirlenmiş durumların } \\
\text { yetersiz kaldığı durumlar olsa bile etik ilkelerine bağlı } \\
\text { kaldığını düşünüyorum. }\end{array}$ & 175 & 2,89 & 1,077 \\
\hline $\begin{array}{l}\text { Ülkemizde meslek mensuplarının etik ilkeleri } \\
\text { uygulamada yeterli özeni gösterdiğini düşünüyorum. }\end{array}$ & 175 & 2,94 & 1,073 \\
\hline $\begin{array}{l}\text { Meslek mensuplarının mesleki kararları dış } \\
\text { etkenlerden etkilenmeden alabildiğini düşünüyorum. }\end{array}$ & 175 & 3,02 & 1,213 \\
\hline $\begin{array}{l}\text { Meslek mensuplarının mükellef-kamu çıkarı } \\
\text { Mentant }\end{array}$ & 175 & 3,04 & 1,152 \\
\hline
\end{tabular}




\begin{tabular}{|c|c|c|c|}
\hline \multicolumn{4}{|l|}{ dengesini eşit şekilde koruduğunu düşünüyorum. } \\
\hline $\begin{array}{l}\text { Mükelleflerin meslek etiğini yeterli saygıyı } \\
\text { gösterdiğini düşünüyorum }\end{array}$ & 175 & 3,07 & 1,065 \\
\hline $\begin{array}{l}\text { Meslek mensuplarının muhasebe ilke ve standartlarını } \\
\text { eksiksiz bir şekilde uyguladıklarını düşünüyorum }\end{array}$ & 175 & 3,25 & 1,110 \\
\hline $\begin{array}{l}\text { Meslek mensuplarının yasaları mümkün olduğunca } \\
\text { mükellef lehine yorumladığını düşünüyorum T }\end{array}$ & 175 & 3,45 & 1,054 \\
\hline $\begin{array}{l}\text { Ülkemizde meslek etiği ile ilgili yasal düzenlemelerin } \\
\text { eksik ve yetersiz olduğunu düşünüyorum T }\end{array}$ & 175 & 3,51 & 1,226 \\
\hline $\begin{array}{l}\text { Meslek mensuplarının mükellef ile ilgili bilgileri } \\
\text { ilgisiz kişilere vermediğini düşünüyorum }\end{array}$ & 175 & 3,55 & 1,363 \\
\hline $\begin{array}{l}\text { Meslek mensuplarının yasalara ve ahlaki değerlere } \\
\text { bağlı kaldığını düşünüyorum. }\end{array}$ & 175 & 3,58 & 1,141 \\
\hline $\begin{array}{l}\text { Meslek mensuplarının mükellefler istediği taktirde } \\
\text { yasalarca uygun görülen bilgileri verdiğini } \\
\text { düşünüyorum }\end{array}$ & 175 & 3,58 & 1,224 \\
\hline $\begin{array}{l}\text { Meslek mensuplarının özgür irade ile karar } \\
\text { verdiklerini düşünüyorum. }\end{array}$ & 175 & 3,59 & 1,141 \\
\hline $\begin{array}{l}\text { Meslek ile ilgili ahlaki değerlerin yasalara } \\
\text { bağlanmasını zor olduğunu düşünüyorum. }\end{array}$ & 175 & 3,59 & 1,274 \\
\hline $\begin{array}{l}\text { Meslek mensuplarının kanunlar çerçevesinde } \\
\text { mükellef hakkını koruduğunu düşünüyorum. }\end{array}$ & 175 & 3,65 & 1,099 \\
\hline $\begin{array}{l}\text { Meslek mensuplarının ilgili taraflara doğru ve yeterli } \\
\text { bilgiyi verdiğini düşünüyorum. }\end{array}$ & 175 & 3,68 & 1,120 \\
\hline $\begin{array}{l}\text { Ülkemizde meslek öncesi etik ilkelerine yönelik } \\
\text { eğitimin yetersiz olduğunu düşünüyorum. T }\end{array}$ & 175 & 3,71 & 1,113 \\
\hline $\begin{array}{l}\text { Meslek mensupları ile mükellefler arasındaki bireysel } \\
\text { ilişkinin etik davranışı etkilediğini düşünüyorum }\end{array}$ & 175 & 3,72 & 1,133 \\
\hline $\begin{array}{l}\text { Meslek mensuplarının gelir düzeyinin etik davranışı } \\
\text { etkilediğini düşünüyorum. }\end{array}$ & 175 & 3,75 & 1,210 \\
\hline $\begin{array}{l}\text { Meslek mensupları etik ilkelerine bağlılığı mesleğe } \\
\text { olan güveni ve saygınlığını arttıracağını } \\
\text { düşünüyorum. }\end{array}$ & 175 & 3,97 & 1,241 \\
\hline $\begin{array}{l}\text { Meslek mensuplarının ilgili taraflara gerektiği zaman } \\
\text { bilgi verdiğini düşünüyorum. }\end{array}$ & 175 & 3,97 & 1,044 \\
\hline $\begin{array}{l}\text { Meslek mensuplarının mesleki gelişmeye açık } \\
\text { olduklarını düşünüyorum. }\end{array}$ & 175 & 4,05 & 1,044 \\
\hline $\begin{array}{l}\text { Meslek mensuplarının mesleki etik kurallarına } \\
\text { uymalarının önemli olduğunu düşünüyorum. }\end{array}$ & 175 & 4,41 & ,879 \\
\hline
\end{tabular}




\begin{tabular}{|l|c|c|c|}
\hline $\begin{array}{l}\text { Etik konusunda eğitim ve öğretimler daha fazla yer } \\
\text { verilmesi gerektiğini düşünüyorum. }\end{array}$ & 175 & 4,41 &, 832 \\
\hline $\begin{array}{l}\text { Meslek mensuplarına yönelik meslek içi eğitim ve } \\
\text { seminerlerin fazlalaştırılmasının etik ilkelerine } \\
\text { bağlılığı arttıracağını düşünüyorum }\end{array}$ & 175 & 4,41 &, 818 \\
\hline *oplam N & 175 & & \\
Toraşarete sahip olan sorular ters sorudur. ters sorular analize alınırken SPSS programı üzerınde "Recode into Same
\end{tabular}
Variables" komutu kullanılarak yeniden kodlanmıștır.

Araştırmada 5'li likert ölçeği kullanılmış ve 1-Hiçbir zaman, 2-Çok Nadiren, 3Arasıra, 4-Sıklikla, 5-Herzaman şeklinde oluşturulmuştur. Buna göre sorulara verilen yanıtların ortalamalarına bakıldığında en yüksek ortalamaya $(4,41)$, "Meslek mensuplarının mesleki etik kurallarına uymalarının önemli olduğunu düşünüyorum", "Etik konusunda eğitim ve öğretimler daha fazla yer verilmesi gerektiğini düşünüyorum”, "Meslek mensuplarına yönelik meslek içi eğitim ve seminerlerin fazlalaştırılmasının etik ilkelerine bağlılı̆̆ arttıracağını düşünüyorum" ifadelerinin yer aldığı görülmektedir. En düşük ortalamaya $(2,23)$, "Meslek mensuplarının mükelleflere ait bilgileri üçüncü kişiler ile paylaştığını düşünüyorum" ifadesine verilen yanıtların oluşturduğunu görmekteyiz.

Standart sapmalar açısından bir değerlendirme yapıldığında, "Meslek mensuplarına yönelik meslek içi eğitim ve seminerlerin fazlalaştırılmasının etik ilkelerine bağlılığ1 arttıracağını düşünüyorum" ifadesinin standart sapmasının aldığı değer $(, 818)$ en düşük sapmaya sahip olduğu, "Meslek mensuplarının mükellef ile ilgili bilgileri ilgisiz kişilere vermediğini düşünüyorum” ifadesinin ise $(1,363)$ en yüksek standart sapma değerine sahip olduğu görülmektedir.

Tablo 3: Muhasebe Meslek Mensupları ve Öğrencilerinin Etik Ölçeklerine Verdikleri Cevapların Boyutlar İtibariyle Ortalama Puanları

\begin{tabular}{|l|r|r|r|r|r|}
\hline & N & Minimum & Maximum & Ortalama & \multicolumn{1}{|c|}{$\begin{array}{c}\text { Standart } \\
\text { Sapma }\end{array}$} \\
\hline Dürüstlük & 175 & 1,00 & 5,00 & 3,1794 &, 77610 \\
Tarafsızlık & 175 & 1,40 & 5,00 & 3,4571 &, 76830 \\
Mesleki Yeterlilik ve & 175 & 2,40 & 5,00 & 3,9657 &, 54895 \\
Özen & 175 & 1,60 & 5,00 & 3,4011 &, 66730 \\
Gizlilik & 175 & 1,80 & 5,00 & 3,7977 &, 67975 \\
Mesleki Davranış & 175 & & & & \\
Geçerli (N) & & &
\end{tabular}


Mesleki etik ilkelerine bakıldığında dürüstlük ölçeğinin $(3,1794)$ en düşük ortalamaya, mesleki yeterlilik ve özen ölçeğine bakıldığında da $(3,9657)$ en yüksek ortalamaya sahip olduğu görülmektedir. Bu durumda gerek meslek mensupları gerekse muhasebe programı öğrencileri muhasebe meslek mensuplarının etik ile ilkelerinin uygulanmasında yeterli olmadığını yani etik ilkelerinin temelinin oluşturan dürüstlük kavramının mesleki noktada olması gerekenden düşük olduğunu düşünmektedirler. Bunun temelinde ise meslek mensupları açısından rekabetin yoğun olması, bazı meslek mensuplarının mesleğine karşı yeterli özeni göstermemesi, mesleki tükenmişlik ile karşı karşıya kalmaları başlıca nedenleri oluşturduğunu söyleyebiliriz. Muhasebe programı öğrencileri açısından ise muhasebe eğitiminde muhasebe etiği altında ayrı bir dersin yer almaması veya mevcut muhasebe derslerinde bu konunun yeterince ele alınmayarak öğrencilerin farkındalık düzeylerinin düşük kalmasıdır diyebiliriz.

Ancak etik ilkelerinden mesleki yeterlilik ve özen ölçeğinde verilen cevapların ortalamalarının yüksek olduğu görülmektedir. Etik ilkelerinin uygulanması ve yerleşik hale gelmesi için gerek eğitim-öğretim gerekse meslek içi eğitim seminerlere daha fazla önem verilmesi görüşü hem meslek mensuplarında hem de muhasebe programı öğrencilerinde hâkimdir.

Muhasebe meslek mensuplarının etik ilkeleri hayata geçirme düzeyleri ile ilgili algılar açısından muhasebe meslek mensupları ile muhasebe programı öğrencileri arasında anlamlı farklılık olup olmadığını test edebilmek için "bağımsız örneklem $t$ testi" kullanılmıştır. Bağımsız Örneklem t testi; iki farklı örneklem grubunun ortalamalarını karşılaş̧ırır. İki grubun üyeleri birbirinden ayrıdır. Böylece, iki ayrı grubun (erkek-kadın vb.) 5‘li Likert ölçeği ile hazırlanmış sorulara verilen cevaplar açısından görüşleri arasında anlamlı bir tutum farklılığının olup olmadığı ölçülecektir. \%95 güven aralığı içerisinde önemlilik (sig.) değeri 0,05’ten küçük çıkmışsa anlamlı bir farkın olduğu anlaşılacaktır (Antalyalı, 2005: 131). Araştırma verilerine göre oluşturulan bağımsız $\mathrm{t}$ testi sonuçları aşağıdaki gibidir.

Tablo 4: Etik Boyutların Uygulanmasına Yönelik Algılamalara İlişkin T Testi Sonuçları

\begin{tabular}{|l|l|c|c|c|c|c|}
\hline $\begin{array}{l}\text { Etik } \\
\text { Boyutları }\end{array}$ & \multicolumn{1}{|c|}{ Unvan } & $\mathbf{N}$ & Ortalamalar & $\begin{array}{c}\text { Ortalama } \\
\text { Farklılıkları }\end{array}$ & $\begin{array}{c}\mathbf{t} \\
\text { Değeri }\end{array}$ & $\begin{array}{c}\text { Anlamlılık } \\
\text { (Sig) }\end{array}$ \\
\hline \multirow{2}{*}{ Dürüstllük } & $\begin{array}{l}\text { Meslek Mensubu } \\
\text { Muhasebe Programı }\end{array}$ & 59 & 3,5356 &, 53732 & 4,570 & \\
& Ögrencisi & 116 & 2,9983 &, 53732 & 4,518 &, 001 \\
\hline & Meslek Mensubu & 59 & 3,8576 &, 60418 & 5,285 &, 001 \\
Muhasebe Programı & 116 & 3,2534 &, 60418 & 5,449 & \\
\hline
\end{tabular}




\begin{tabular}{|c|c|c|c|c|c|c|}
\hline $\begin{array}{l}\text { Mesleki } \\
\text { Yeterlilik } \\
\text { ve Özen }\end{array}$ & $\begin{array}{l}\text { Meslek Mensubu } \\
\text { Muhasebe Programı } \\
\text { Öğrencisi }\end{array}$ & $\begin{array}{r}59 \\
116\end{array}$ & $\begin{array}{l}4,0542 \\
3,9207\end{array}$ & $\begin{array}{l}13355 \\
, 13355\end{array}$ & $\begin{array}{l}1,527 \\
1,456\end{array}$ & ,129 \\
\hline Gizlilik & $\begin{array}{l}\text { Meslek Mensubu } \\
\text { Muhasebe Programı } \\
\text { Öğrencisi }\end{array}$ & $\begin{array}{c}59 \\
116\end{array}$ & $\begin{array}{l}3,5186 \\
3,3414\end{array}$ & $\begin{array}{l}, 17726 \\
, 17726\end{array}$ & $\begin{array}{l}1,670 \\
1,632\end{array}$ &, 106 \\
\hline $\begin{array}{c}\text { Mesleki } \\
\text { Davranış }\end{array}$ & $\begin{array}{l}\text { Meslek Mensubu } \\
\text { Muhasebe Programı } \\
\text { Öğrencisi }\end{array}$ & $\begin{array}{r}59 \\
116\end{array}$ & $\begin{array}{l}3,8678 \\
3,7621\end{array}$ & $\begin{array}{l}, 10573 \\
10573\end{array}$ & $\begin{array}{r}, 973 \\
1,069\end{array}$ & ,287 \\
\hline
\end{tabular}

Tabloda görülen sonuçlara göre; "Dürüstlük" ilkesinin muhasebe meslek mensuplarınca uygulanmasına yönelik algılamalar açısından farklılık vardır. Muhasebe meslek mensupları ile muhasebe programı öğrencileri arasında anlamlı algılama fark1 bulunmaktadır ( $\alpha=0,05$ iken, çift yönlü $\rho \leq 0,001)$. Buna göre, meslek mensupları öğrencilere kıyasla dürüstlük ilkesine uygulamada daha az riayet edildiğini düşünmektedirler.

Benzer bir durum "Tarafsızlık” ilkesi açısından da söz konusudur. Muhasebe meslek mensupları ile muhasebe programı öğrencileri arasında anlamlı algılama farkı bulunmaktadır ( $\alpha=0,05$ iken, çift yönlü $\rho \leq 0,001)$. Buna göre, meslek mensupları öğrencilere kıyasla tarafsızlık ilkesine uygulamada daha az riayet edildiğini düşünmektedirler. Öğrenciler, üçüncü kişilerin haksız ve uygunsuz biçimde yaptıkları baskıların meslek mensuplarının mesleki kararlarını etkilediğini meslek mensuplarına kıyasla daha fazla düşünmektedirler. Diğer ilkeler açısından ise iki grup arasında herhangi bir algılama farklılığı söz konusu değildir.

\section{SONUÇ}

Muhasebe meslek mensuplarının kanunlar ve toplumsal değerlerin önemi doğrultusunda doğru, tarafsız, güvenilir bilgiler üretme ve topluma sunma durumundadır. Meslek mensuplarının bahsedilen faaliyetleri ile birlikte mükellefler, meslektaşlar ve meslek kuruluşları ile ilişkilerinde uymaları gereken kurallar meslek etiğini oluşturmaktadır. Meslek mensuplarının mesleğin saygınlığını arttırmaları ve mesleği daha ileri boyuta taşıyabilmeleri yani mesleğin geleceği açısından meslek etiği önemli bir unsura sahiptir.

Her meslek dalında uyulması gereken ahlaki değerler bulunduğu gibi muhasebecilik mesleğinde de etik değerler bulunmakta ve ülkemizde buna ilişkin düzenlemeler bulunmaktadır. Daha öncede bahsedildiği üzere TÜRMOB tarafindan 19.10.2007 tarihinde "Serbest Muhasebeciler, Serbest Muhasebeci Mali Müşavirler ve Yeminli Mali Müşavirlerin Mesleki Faaliyetlerinde Uyacakları Etik İlkeler Hakkında Yönetmelik” yayınlanmıştır. Bu yönetmeliğe göre, temel etik ilkeleri dürüstlük, tarafsızlık, mesleki yeterlilik ve özen, gizlilik ve mesleki davranış olarak sınıflandırılmıştır. Bu temel ilkelerin hayata geçirilmesi demek, 
hali hazırda meslek erbabı olan bireylerin bu ilkelerden taviz vermeden iş ve eylemlerini yapması demektir.

Bir bireyin herhangi bir olay veya olgu ile ilgili algılaması o olay veya olguya ilişkin duygu organları vasıtasıyla dış dünyadan elde ettiği verilerin zihninde yorumlanması sonucu gerçekleşecektir. Ancak, birey, zihninde bu yorumlamayı yaparken, kişiliğinden, tecrübelerinde ve tüm sosyal yaşantılarından etkilenecektir. Dolayısıyla, muhasebe meslek mensuplarının ve öğrencilerinin mesleği icra ederken uyulması gereken ilkelere ne derece uyulduğuna ilişkin algılamaları bu konuyla ilgili yaşantılar, duyumlar, dedikodular ve dışsal bilgiler sayesinde şekillenecektir. Örneklem çerçevesinde, etik ilkelere meslek mensuplarınca ne düzeyde riayet edildiğine dair verilen cevapların genel ortalamalarına bakıldığında orta düzeyde olumlu bir algılamanın olduğu söylenebilir. Elde edilen ortalamaların "3-Ara Sıra" ve "4-Sıklıkla" seçeneklerine yakın işaretlendiği görülmüştür. Konumuza ilgili olarak gerçek hayatta istenen, verilen cevapların ortalamalarının 5'e yakın olmasıdır ki, meslek mensuplarının etik ilkeleri hayata geçirip geçirmemesiyle ilgili algı mesleğin içinde olan insanlar tarafinda olumlu olsun. Bu durum aslında genel anlamda etik ilkelere uygun hareket etme noktasında meslek mensupları bağlamında noksanlıkların olduğunun hem öğrenciler hem de meslek mensuplarınca kabul edildiği görüşü ileri sürülebilir.

Fakat ilkelerin uygulanmasına yönelik algılama puanlarını öğrenci veya meslek mensubu taraflarından ayrı ayrı da ele almak gerekmektedir.

$\mathrm{Bu}$ nedenle yukarıda "bağımsız örneklem $\mathrm{t}$ testi" vasitasıyla elde ettiğimiz neticeler itibariyle öğrencilerin yaşantılar, duyumlar, dedikodular ve dışsal bilgiler sayesinde meslek mensuplarının özellikle "dürüstlük" ve "tarafsızlı" ilkelerinin uygulanması noktasında zafiyet gösterdiklerini düşündükleri söylenebilir. Meslek mensuplarının uygulamanın içerisinde olması sebebiyle dürüst ve tarafsız hareket ettiklerini iddia etmeleri doğal bir sonuç olarak görülebilir. Diğer taraftan, öğrencilerin mesleğe hazırlanan bireyler olarak, hali hazırda mesleği icra eden insanların dürüstlük ve tarafsızlık düzeyleri konusunda daha olumsuz bir algılamaya sahip olmaları da üzerinde düşünülmesi gereken bir durumdur. Özellikle staj vb. gibi sebeplerle meslek mensuplarının yanında çalışan öğrencilerin tanık olduğu olaylar böyle bir algılamaya neden olabileceği gibi, tüm toplumun bu konuda sahip olduğu bir algılamanın yansıması da söz konusu olabilir. Ayrıca, bizzat işin içinde olan meslek erbabının muhasebecilik mesleği ile ilgili içsel ve dışsal koşulları tecrübe edinmeleri bu ilkelere uygun hareket etmenin bu koşullar nedeniyle kolay olmadığını bilmeleri de söz konusudur. Çünkü çoğu meslekte olduğu gibi muhasebecilik mesleğinde de meslek erbabı vicdanı ile cüzdanı arasında ki gerilimi bizzat yaşamaktadır. Öğrencilerin mesleği etkileyen tüm koşulları yakinen tecrübe edinmemeleri önyargılı ya da kolaycı bir bakış açısına sahip olmalarına neden olmuş olabilir. 


\section{KAYNAKLAR}

Acar, Durmuş -Tetik, Nilüfer (2006), Tek Düzen Hesap Planı ve Türkiye Muhasebe Standartlarına Uygun Genel Muhasebe, 5. Bask1, Detay Yayıncılık, Ankara.

Antalyal1, Ömer (2005), Varyans Analizi (Anova-Manova), Kalaycı, Şeref (Der.), SPSS Uygulamalı Çok Değişkenli İstatistik Teknikleri, Asil Yayın, Ankara.

Aymankuy,Yusuf-Sarığlan, Mehmet (2005), "Muhasebe Meslek Mensuplarının Meslek Etiğine Yaklaşımları ve Balıkesir İl Merkezinde Bir Uygulama”, Balıkesir Üniversitesi Sosyal Bilimler Enstitüsü Dergisi, Cilt:8, Sayı:14, Aralık, s. 23-45.

İşgüden, Burcu-Çabuk, Adem (2006), "Meslek Etiği ve Meslek Etiğinin Meslek Yaşamı Üzerindeki Etkileri”, Balıkesir Üniversitesi Sosyal Bilimler Enstitüsü Dergisi, Cilt:9, Sayı:16, Aralık,s. 59-86.

Nalbantoğlu, Rıfat, "Muhasebe Uygulamaları Konusunda Meslek Mensuplarının Bakış Açıları", http://archive.ismmmo.org.tr/docs/sempozyum/06Sempozyum/5Oturum/RifatNalbant oglu.pdf. (Erişim Tarihi:13.01.2014).

Pojman, Louis P.- Fieser, James (2009), Ethics (Discovering Right and Wrong), Cengage Learning, Wadsworth.

Ünsal, Ahmet (2008), “İşletmelerde Muhasebe Yöneticilerinin Etiksel Karar Süreci”, Karamanoğlu Mehmetbey Üniversitesi İ̈BF Dergisi, Sayı:14, s. 1-19.

Sakarya, Şakir-Kara, Suat (2010), “Türkiye'de Muhasebe Meslek Etiğine Yönelik Düzenlemeler ve Meslek Mensupları Tarafindan Algılanması Üzerine Bir Alan Araştırması”, Karamanoğlu Mehmetbey Üniversitesi Sosyal ve Ekonomik Araştırmalar Dergisi, Cilt:12, Sayı:18, s. 57-72.

Strahlendorf, Peter, Professional Ethics, http://www.bcsp.org/pdf/presentationsarticles/714_1.pdf, (Erişim Tarihi:11.01.2014)

Taştan Abdulkerim (2009), "Etik Eğitiminin Muhasebe Eğitimindeki Yeri ve Önemi: Türkiye Değerlendirmesi”, Marmara Üniversitesi İ̈BF Dergisi, Sayı:1 s.281-311.

Uçma Tuğba (2007), Muhasebe Meslek Mensubu Olmak İsteyenlerin Etik Değer Anlayışının Belirlenmesi ve Muğla Üniversitesi Uygulaması, Muğla Üniversitesi Sosyal Bilimler Enstitüsü Yüksek Lisans Tezi, Haziran s.36-38.

Yardımcıoğlu, Mahmut- Büyükşalvarcı, Ahmet-İyibildiren Mustafa (2006), "Etiksel Açıdan Yeminli Mali Müşavirlerin Sorumluluklarının Konya İli Özelinde İncelenmesi”, Selçuk Üniversitesi Karaman İ̈BF Dergisi, Sayı:11, Aralık, s. 170-180.

Y1lmaz, Gülsevil (2010), "Muhasebe Mesleğinde Meslek Etiği ve Kayseri İl Merkezinde Bir Uygulama”, Erciyes Üniversitesi İktisadi ve İdari Bilimler Fakültesi Dergisi, Sayı 36, Aralık, ss. $155-178$.

Yatkın, Ahmet (2008), "Etik Düşünce ve Davranışın Yerel Yönetimlerde Hizmet Verimliliğinin Arttırılmasında Rolü ve Önemi (Elazı̆̆ Belediyesi Örnek Alan Araştırma)", Fırat Üniversitesi Sosyal Bilimler Dergisi, Cilt:18, Sayı:1, s. 211- 231.

http://www.resmigazete.gov.tr/eskiler/2007/10/20071019-8.htm (Erişim Tar.03.01.2014). 
